\title{
Explicit modeling of volatile organic compounds partitioning in the atmospheric aqueous phase
}

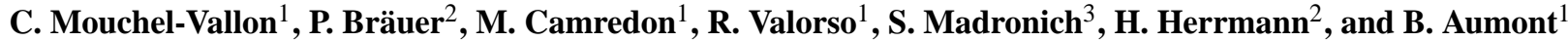 \\ ${ }^{1}$ Laboratoire Interuniversitaire des Systèmes Atmosphériques, UMR7583, CNRS/INSU, Université Paris \\ Est Créteil et Université Paris Diderot, Institut Pierre Simon Laplace, 94010, Créteil, France \\ ${ }^{2}$ Leibniz-Institut für Troposphärenforschung, Permoserstr. 15, 04318 Leipzig, Germany \\ ${ }^{3}$ NCAR, National Center for Atmospheric Research, Boulder, Colorado, USA
}

Correspondence to: B. Aumont (bernard.aumont@lisa.u-pec.fr)

Received: 14 August 2012 - Published in Atmos. Chem. Phys. Discuss.: 14 September 2012

Revised: 14 January 2013 - Accepted: 16 January 2013 - Published: 25 January 2013

\begin{abstract}
The gas phase oxidation of organic species is a multigenerational process involving a large number of secondary compounds. Most secondary organic species are water-soluble multifunctional oxygenated molecules. The fully explicit chemical mechanism GECKO-A (Generator of Explicit Chemistry and Kinetics of Organics in the Atmosphere) is used to describe the oxidation of organics in the gas phase and their mass transfer to the aqueous phase. The oxidation of three hydrocarbons of atmospheric interest (isoprene, octane and $\alpha$-pinene) is investigated for various $\mathrm{NO}_{\mathrm{x}}$ conditions. The simulated oxidative trajectories are examined in a new two dimensional space defined by the mean oxidation state and the solubility. The amount of dissolved organic matter was found to be very low (yield less than $2 \%$ on carbon atom basis) under a water content typical of deliquescent aerosols. For cloud water content, $50 \%$ (isoprene oxidation) to $70 \%$ (octane oxidation) of the carbon atoms are found in the aqueous phase after the removal of the parent hydrocarbons for low $\mathrm{NO}_{\mathrm{x}}$ conditions. For high $\mathrm{NO}_{\mathrm{x}}$ conditions, this ratio is only $5 \%$ in the isoprene oxidation case, but remains large for $\alpha$-pinene and octane oxidation cases (40\% and $60 \%$, respectively). Although the model does not yet include chemical reactions in the aqueous phase, much of this dissolved organic matter should be processed in cloud drops and modify both oxidation rates and the speciation of organic species.
\end{abstract}

\section{Introduction}

The atmospheric aqueous phase includes water in clouds and fogs droplets and deliquescent particles. The reactivity of inorganic compounds in atmospheric water and their contribution to particulate matter formation has been extensively studied (e.g. Finlayson-Pitts and Pitts, 2000; Kreidenweis et al., 2003; Monod and Carlier, 1999). However large uncertainties still remain about the fate of dissolved organics. Most secondary organic species produced during gas phase oxidation are water-soluble multifunctional oxygenated species. Because gas phase oxidation mechanisms are unable to reproduce experimental secondary organic aerosol (SOA) yields (Carlton et al., 2009; Ervens et al., 2011; Hallquist et al., 2009), aqueous phase mediated SOA formation is currently studied as a way to enhance aerosol yields (Carlton et al., 2009; El Haddad et al., 2009; Ervens and Volkamer, 2010; Ervens et al., 2008, 2011; Fu et al., 2009; Hallquist et al., 2009; Lim et al., 2010).

The study of aqueous phase chemistry as a potential source of SOA has shown that oxidation in water of secondary species could contribute to SOA mass. For example, Lim et al. (2005) have shown in a modeling study that the cloud oxidation of aldehydes originating from isoprene oxidation could be responsible for 4-20\% of the total isoprene SOA yield. Similarly, Myriokefalitakis et al. (2011) have shown that cloud chemistry could enhance oxalate production by $2 \mathrm{Tg} \mathrm{yr}^{-1}$, a contributor to SOA mass. Ervens and Volkamer (2010) modeled the SOA formation through aqueous phase processing of glyoxal, one of the oxidation products of 
isoprene. Their simulations based on observations in chamber experiments by Volkamer et al. (2009) have confirmed that there is a correlation between SOA mass increase and the liquid water content $(L)$. Focusing on the aqueous oxidation of glyoxal, methylglyoxal and glycolaldehyde, Lim et al. (2005) and following studies (Tan et al., 2009, 2010) showed that aqueous processing of isoprene oxidation products could yield SOA through the formation of organic acids. Biogenic terpenes SOA yields from gas phase photooxidation have been explored in detail (e.g. Hallquist et al., 2009). Several recent experimental works have studied the influence of aqueous phase photooxidation on the composition of SOA formed after oxidation of biogenic compounds (Lee et al., 2011, 2012; Bateman et al., 2011). As for anthropogenic hydrocarbons, recent experimental results from Zhou et al. (2011) suggest that SOA yields of four aromatic hydrocarbons (toluene and xylenes) are correlated to the ambient liquid water.

The mechanism of volatile organic compound (VOC) processing by the aqueous phase can be split in two steps:

i. Phase partitioning. Specifically, many secondary organic species formed during the gas phase oxidation of hydrocarbons are highly soluble and have been found in atmospheric water (e.g. Chebbi and Carlier, 1996; van Pinxteren et al., 2005; Sorooshian et al., 2007; Matsunaga et al., 2007).

ii. Aqueous phase reactivity. Like in the gas phase, dissolved compounds are oxidized by radicals in water, mainly by $\mathrm{OH}$ and $\mathrm{NO}_{3}$ (Herrmann, 2003; Warneck, 2005; Lim et al., 2010). Resulting products are similar to those observed in the gas phase, but branching ratios substantially differ from the gas phase (e.g. Herrmann, 2003; Poulain et al., 2010). Moreover in the aqueous phase, hydration and acid dissociation can occur, which lead to the formation of some organic products (hydrates and carboxylate ions) not formed in the gas phase. Additional processes forming heavier species can take place in the aqueous phase, like esterification and aldol condensation (e.g. Nguyen et al., 2011; Altieri et al., 2008; Lim et al., 2010).

As experimental studies inside clouds are scarce and very difficult to set up (Crahan et al., 2004; Herrmann et al., 2005; Sorooshian et al., 2007), most of the organics clouds chemistry studies have been performed based on modeling approaches. These models usually represent the condensed phase as a single well mixed aqueous phase in which organic species undergo oxidation. This aqueous oxidation scheme is coupled with specifically tailored gas phase mechanisms taking into account mass transfer between the two phases (e.g. Jacob, 1986; Lelieveld and Crutzen, 1991; Leriche et al., 2000; Barth et al., 2003; Lim et al., 2005; Ervens et al., 2008; Tilgner and Herrmann, 2010). Current detailed models are limited to certain kinds of species. For example, the model from Ervens and Volkamer (2010) has been developed to study isoprene and its oxidation products like glyoxal. The CAPRAM 3.0i mechanism used by Tilgner and Herrmann (2010) is currently the most detailed aqueous phase organic chemistry model, taking into account the dissolution and aqueous chemistry of inorganic species and organic species up to four carbon atoms. However, atmospheric processing of long chain hydrocarbons is also expected to lead to the production of highly water soluble multifunctional organics in a few oxidation steps (e.g. van Pinxteren et al., 2005; Mazzoleni et al., 2010). The fraction of these compounds that could be subjected to aqueous phase processing has yet to be determined. To our knowledge, no modeling tool is currently available to describe in detail the multiphase oxidation of long chain hydrocarbons. This study describes the first stage in the development of such a modeling tool and examines the phase partitioning of organic species produced during the gas phase oxidation of hydrocarbons.

This study is devoted to the production of water soluble compounds from the gaseous oxidation of long chain hydrocarbons of atmospheric interest and the sensitivity of this dissolution to $\mathrm{NO}_{\mathrm{x}}$ levels. A fully explicit chemical mechanism is used to describe the oxidation of organics in the gas phase and their mass transfer to the aqueous phase. Note that chemical evolution in the condensed phase is not represented in this modeling framework. Aqueous phase reactivity has been shown as a key process in the production of SOA (e.g. Ervens et al., 2011) and estimation of SOA yields is beyond of the scope of this study. The gas phase oxidation of three hydrocarbons of atmospheric interest (isoprene, octane and $\alpha$-pinene) is investigated for various $\mathrm{NO}_{\mathrm{x}}$ conditions. Two scenarios are considered with a liquid water content corresponding either to a cloud or to deliquescent particles. The simulated carbon budget and the composition of the gas and aqueous phase are explored in detail.

\section{Modeling tools}

\subsection{Gas phase chemistry}

Aqueous phase oxidation involves water soluble species produced during the gaseous phase oxidation of volatile organic compounds (VOC) (e.g. Ervens et al., 2011). Candidate species are typically highly functionalized molecules produced during the multigenerational oxidation of the hydrocarbons emitted in the atmosphere. The number of species needed to describe explicitly this multigenerational oxidation increases exponentially with the size of the carbon skeleton of the parent compound (Aumont et al., 2005). For long chain species $\left(\mathrm{C}_{>5}\right)$, explicit oxidation schemes involve a number of intermediates that far exceeds the size of chemical schemes that can be written manually. The Generator for Explicit Chemistry and Kinetics of Organics in the Atmosphere (GECKO-A) is a computer tool that was developed 
to overcome this difficulty (Aumont et al., 2005). GECKO-A generates gas phase chemical schemes according to a prescribed protocol, assigning reaction pathways and kinetics data, on the basis of experimental data and structure activity relationships.

The GECKO-A protocol is described by Aumont et al. (2005). This protocol was updated to take into account recent experimental results. The branching ratios for the isoprene $+\mathrm{OH}$ reaction have been prescribed following recommendations from Paulot et al. (2009a). As proposed by Paulot et al. (2009b), a new oxidative pathway for hydroperoxides has been added in the protocol, forming epoxides. In this model formulation, it is assumed that all epoxides are converted to diols. This allows the formation of tetrol species that were detected as isoprene oxidation products. The first oxidation steps of $\alpha$-pinene and alkane chemistry were also updated, as described by Valorso et al. (2011) and Aumont et al. (2012).

Explicit schemes generated with GECKO-A reach 1 million species for $\mathrm{C}_{8}$ compounds, close to current computational limits (Camredon et al., 2007). A reduction protocol was therefore implemented in GECKO-A to allow the generation of oxidation schemes for $\mathrm{C}_{>8}$ hydrocarbons (Valorso et al., 2011). The reduction protocol was designed to keep the oxidation schemes as detailed as possible, without losing the chemical information that determines molecular properties such as reactivity or volatility. The reduction approaches currently implemented in GECKO-A are based on the lumping of position isomers. For the purpose of this study, we also reduced the size of the chemical schemes by omitting the gas phase oxidation reactions for the highly soluble species, as it was done by Valorso et al. (2011) for non-volatile organic species. At thermodynamic equilibrium, the distribution of a species $i$ between the gas and the aqueous phase is given by:

$\xi^{i}=\frac{N_{\mathrm{a}}^{i}}{N_{\mathrm{a}}^{i}+N_{\mathrm{g}}^{i}}=\left(1+\frac{1}{H^{i} R T L}\right)^{-1}$

where $N_{\mathrm{a}}^{i}$ and $N_{\mathrm{g}}^{i}$ [molec $\mathrm{cm}^{-3}$ of air] are its number concentrations in the aqueous and gas phase respectively, $H^{i}$ $\left[\mathrm{M} \mathrm{atm}^{-1}\right]$ is the Henry's law coefficient for the species, $R$ is the gas constant, $T$ the temperature and $L$ the liquid water content $\left[\mathrm{cm}^{3}\right.$ liquid water per $\mathrm{cm}^{3}$ air]. For a small tropospheric liquid water content (ca. $L=10^{-12}$ ), $\xi^{i}$ is greater than 0.99 for $H^{i}$ greater than $10^{12} \mathrm{M} \mathrm{atm}^{-1}$. Under most atmospheric conditions, a species having a Henry's law constant above $10^{12} \mathrm{M} \mathrm{atm}^{-1}$ is therefore expected to be predominantly in the aqueous phase. For such species, gas phase concentration is negligible and their gas phase chemistry was thus omitted.

\subsection{Phase transfer}

For each water soluble species A, the mass transfer between the gas and the aqueous phase is treated in a time dependent sense:

$\mathrm{A}(\mathrm{g}) \rightarrow \mathrm{A}(\mathrm{aq}) \quad k_{\mathrm{I}}$

$\mathrm{A}(\mathrm{aq}) \rightarrow \mathrm{A}(\mathrm{g}) \quad k_{\mathrm{I}} / H_{\mathrm{A}}$

where $k_{\mathrm{I}}\left[\mathrm{s}^{-1}\right]$ is the pseudo first order rate constant of the gas-particle mass transfer and $H_{\mathrm{A}}\left[\mathrm{M} \mathrm{atm}^{-1}\right]$ is the Henry's law coefficient for the species A. The rate constant $k_{\mathrm{I}}$ can be expressed as (Schwartz, 1986):

$k_{\mathrm{I}}=L k_{\mathrm{T}}=L\left(\frac{r^{2}}{3 D_{\mathrm{g}}}+\frac{4 r}{3 v \alpha}\right)^{-1}$

where $r[\mathrm{~cm}]$ is the radius of the particles or the droplets, $D_{\mathrm{g}}\left[\mathrm{cm}^{2} \mathrm{~s}^{-1}\right]$ is the gas diffusion coefficient, $v\left[\mathrm{~cm} \mathrm{~s}^{-1}\right]$ is the mean molecular speed and $\alpha$ [dimensionless] is the mass accommodation coefficient. The diffusion coefficient $D_{\mathrm{g}}$ can be estimated by scaling from a known reference compound:

$\frac{D_{\mathrm{g}}}{D_{\mathrm{g}, \text { ref }}}=\sqrt{\frac{M_{\mathrm{ref}}}{M}}$

where $M\left[\mathrm{~g} \mathrm{~mol}^{-1}\right]$ is the molar mass and "ref" subscripts denote values for a reference species. We used water as reference compound, $D_{\mathrm{g}, \mathrm{H}_{2} \mathrm{O}}=0.214 / \mathrm{P} \mathrm{cm}^{2} \mathrm{~s}^{-1}$ in air at $298 \mathrm{~K}$ (Ivanov et al., 2007), $P$ [atm] being the atmospheric pressure. $H$ is taken from the literature when available, using the database compiled by Raventos-Duran et al. (2010, Supplement) for ca. 600 species. The empirical group contribution method GROMHE was used to estimate unknown constants (Raventos-Duran et al., 2010). GROMHE is able to estimate Henry's law constants at temperature $T=298 \mathrm{~K}$ for every atmospherically relevant organic species. The temperature dependence of $H$ is represented with the Van't Hoff equation:

$H(T)=H(298) \times \exp \left(\frac{\Delta H_{\text {solv }}}{R}\left(\frac{1}{298}-\frac{1}{T}\right)\right)$

The enthalpy of dissolution $\Delta H_{\text {solv }}\left[\mathrm{J} \mathrm{mol}^{-1}\right]$ is also taken from the literature when available, using the database compiled by Raventos-Duran et al. (2010, Supplement). $\Delta H_{\text {solv }}$ typically ranges from 10 to $100 \mathrm{~kJ} \mathrm{~mol}^{-1}$ (Kuhne et al., 2005) and a value of $50 \mathrm{~kJ} \mathrm{~mol}^{-1}$ was used as a default value in the model. The mass accommodation coefficient $\alpha$ is very poorly documented (ca. 40 constants in the literature, Davidovits et al., 2011; Sander et al., 2011). To our knowledge, the only SAR available to estimate $\alpha$ was proposed by Davidovits et al. (1995) and Nathanson et al. (1996). However the performances of that method cannot be rigorously evaluated due to the lack of experimental data. This method has therefore not been implemented and when no data are available, $\alpha$ is set to a default value of $\alpha=0.05$ (Davidovits et al., 2011).

In this version of the model devoted to examine the phase partitioning of organics produced during gas phase processing, the only reactions taken into account in water are: 
Table 1. Number of species generated in the full chemical schemes for the three precursor species.

\begin{tabular}{lccc}
\hline & \multicolumn{3}{c}{$\begin{array}{c}\text { Number of species in the } \\
\text { generated chemical mechanism }\end{array}$} \\
\cline { 2 - 4 } $\begin{array}{l}\text { Precursor } \\
\text { species }\end{array}$ & $\begin{array}{c}\text { Gas } \\
\text { phase }\end{array}$ & $\begin{array}{c}\text { Aqueous } \\
\text { phase }\end{array}$ & Total \\
\hline Isoprene & $5.9 \times 10^{3}$ & $3.2 \times 10^{3}$ & $9.1 \times 10^{3}$ \\
Octane & $1.1 \times 10^{5}$ & $5.0 \times 10^{4}$ & $1.6 \times 10^{5}$ \\
$\alpha$-pinene & $3.2 \times 10^{5}$ & $2.5 \times 10^{5}$ & $5.6 \times 10^{5}$ \\
\hline
\end{tabular}

i. Hydration of carbonyls. Species bearing ketone or aldehyde moieties undergo hydration equilibrium once they are dissolved. Equilibrium constants are estimated using the SAR from Raventos-Duran et al. (2010).

ii. Dissociation of acids. Carboxylic acids undergo acid/base equilibrium in water. Acidity constant are estimated following recommendations from Perrin et al. (1981).

Species are therefore not further oxidized in water. In the model, the only sink for the dissolved organic matter is caused by the gas phase chemical pump that shifts the water/gas equilibrium. For very soluble species, gas phase oxidation becomes slow and the species remain in the aqueous phase in a form that can be considered as "permanent" in this version of the model.

\subsection{Initial conditions}

The modeling framework described above has been applied to the generation of the detailed mechanisms for three species of atmospheric interest: isoprene, octane and $\alpha$-pinene. Table 1 gives the total number of species after the complete generation of these chemical schemes. The number of species generated in the aqueous phase is in the same order of magnitude as the number of species generated in the gas phase. The phase partitioning is considered for non radical species only, but gem-diols (carbonyl hydration) and carboxylates (acid dissociation) are newly formed in water. Some of these newly formed species are highly soluble and therefore are not transferred to the gas phase. Partitioning of acids is $\mathrm{pH}$ dependent. The $\mathrm{pH}$ of the aqueous phase was set to a value of 4.5, typical of clouds (e.g. Brüggemann et al., 2005).

The objective is to simulate the evolution of different hydrocarbons in order to characterize the multiphase partitioning of their reaction products at different stages of the oxidation. No attempt is made here to represent a specific situation. The initial concentration of the precursor was set to $10 \mathrm{ppb}$. The simulations were run with constant environmental conditions. Temperature was fixed to $278 \mathrm{~K}$. Photolysis frequencies were calculated for mid-latitude and for a solar zenith angle of $45^{\circ}$ using TUV (Madronich and Flocke,
1997). $\mathrm{NO}_{\mathrm{x}}$ concentrations were held constant and three scenarios were considered corresponding to low $\mathrm{NO}_{\mathrm{x}}(0.1 \mathrm{ppb})$, intermediate $\mathrm{NO}_{\mathrm{x}}(1 \mathrm{ppb})$ and high $\mathrm{NO}_{\mathrm{x}}(10 \mathrm{ppb})$ conditions. For parent hydrocarbons bearing a double bond (isoprene and $\alpha$-pinene), the distribution of secondary organic species depends on the concentration ratio of the oxidants as well $\left(\mathrm{OH}\right.$ and $\left.\mathrm{O}_{3}\right)$. Ozone and an $\mathrm{OH}$ source were therefore added in the initial conditions to allow both $\mathrm{VOC}+\mathrm{O}_{3}$ and $\mathrm{VOC}+\mathrm{OH}$ oxidation. An initial mixing ratio of $40 \mathrm{ppb}$ of $\mathrm{O}_{3}$ is used in the simulations and a constant $\mathrm{OH}$ source $\left(10^{7}\right.$ radicals $\left.\mathrm{cm}^{-3} \mathrm{~s}^{-1}\right)$ was added as a substitute of radical sources not taken into account in the simulations. In these conditions, depending on the parent hydrocarbon, organic oxidation can be driven by $\mathrm{OH}, \mathrm{O}_{3}$ or both. In this model configuration, the contribution of $\mathrm{OH}$ (97\% of the total oxidation of the precursor) is one order of magnitude higher than the contribution of $\mathrm{O}_{3}(3 \%)$ to the oxidation of isoprene; $\mathrm{OH}$ and $\mathrm{O}_{3}$ contribute comparably ( $61 \%$ and $39 \%$, respectively) to the oxidation of $\alpha$-pinene; octane is only oxidized by $\mathrm{OH}$.

\section{Results}

\subsection{Carbon budget and liquid water content}

Figure 1 shows the time evolution of the carbon atom ratio during the oxidation of isoprene, octane and $\alpha$-pinene. Simulations were performed for three liquid water conditions: without aqueous phase $(L=0)$, with a water content representative of deliquescent aerosols $\left(L=10^{-12}\right.$, e.g. Engelhart et al., 2011) and for typical cloud conditions $\left(L=3 \times 10^{-7}\right.$, e.g. Seinfeld and Pandis, 2006). We assume that the particle and cloud droplet sizes are monodisperse, with particle radii of $0.1 \mu \mathrm{m}$ and $5 \mu \mathrm{m}$, respectively. Simulations are shown for a $\mathrm{NO}_{\mathrm{x}}$ concentration set to $1 \mathrm{ppb}$.

Physical time is not fully appropriate to describe the temporal evolution for simulations conducted under constant environmental conditions. The temporal evolution is examined below as a function of the number of lifetimes $N_{\tau}$ of the parent hydrocarbon defined as:

$$
N_{\tau}=\ln \frac{C_{0}}{C(t)}=\frac{t}{\tau}
$$

where $t$ is the simulated (physical) time, $\tau$ is the e-folding lifetime of the parent hydrocarbon (i.e. the time required to decrease its concentration by a factor $1 / e), C_{0}$ and $C(t)$ its concentration at $t_{0}$ and $t$, respectively. For these simulations, lifetimes of isoprene, $\alpha$-pinene and octane were approximately $1 \mathrm{~h}, 1.5 \mathrm{~h}$ and 1 day, respectively.

Under dry conditions $(L=0)$, isoprene is slowly oxidized into $\mathrm{CO}$ and $\mathrm{CO}_{2}$ through a multigenerational process involving the formation of successive gaseous secondary intermediates of higher oxidation state (see Fig. 1a). The carbon budget is not affected by the presence of an aqueous phase representative of deliquescent aerosols (not shown). 


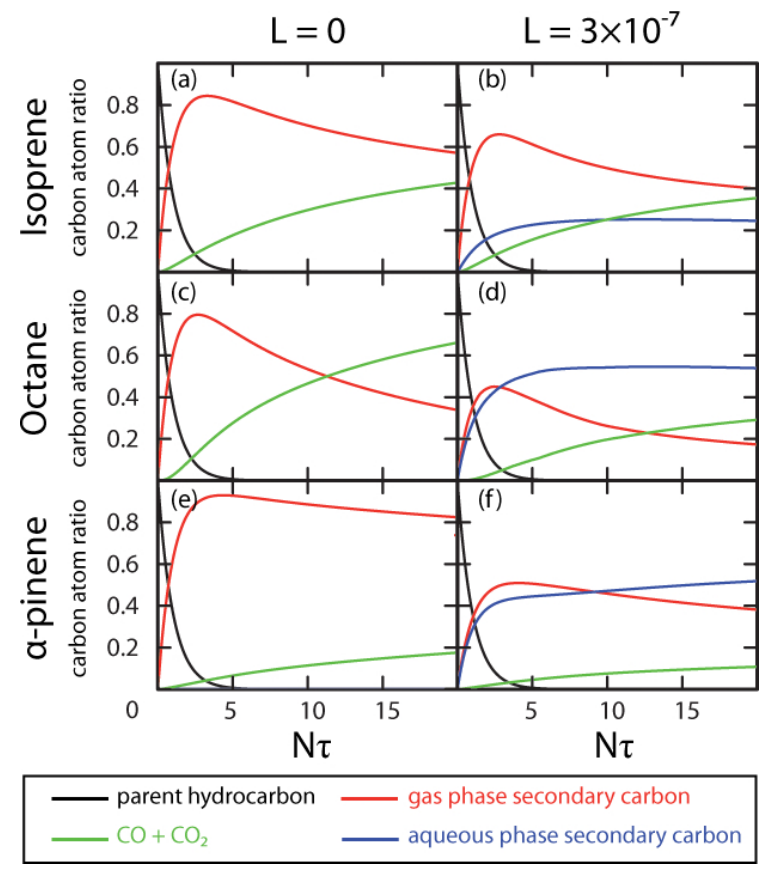

Fig. 1. Carbon budget during the oxidation of isoprene (top row), octane (middle row) and $\alpha$-pinene (bottom row) for liquid water content of 0 ( 1 st column) and $3 \times 10^{-7}$ ( 2 nd column), under intermediate $\mathrm{NO}_{\mathrm{x}}$ conditions $\left(\mathrm{NO}_{\mathrm{x}}=1 \mathrm{ppb}\right)$. The time scale is defined as multiples of lifetimes of the initial hydrocarbon, as described in the text.

Dissolved organic carbon accounts for less than $1 \%$ of the carbon atom ratio. With such low water content, only the more soluble species contribute to the organic content of the aqueous phase, i.e. the more functionalized species. The top 10 contributors to the aqueous phase composition are $\mathrm{C}_{5}$ species bearing 4 functional groups each. For $L$ set to a cloud value (Fig. 1b), less soluble species contribute substantially to aqueous phase organic mass. As a consequence, at the end of the simulation, $25 \%$ of the total carbon initially in the isoprene backbone is found in water.

The carbon budget during octane oxidation is depicted in Fig. 1c for dry conditions. Gas phase secondary organic carbon reaches a peak for $N_{\tau}=2.5$. This secondary organic fraction is progressively oxidized, ultimately leading to $\mathrm{CO}+\mathrm{CO}_{2}$ with a yield of $66 \%$ for $N_{\tau}=20$. Note that the production of $\mathrm{CO}$ and $\mathrm{CO}_{2}$ at a given $N_{\tau}$ is comparatively higher for octane, owing to its greater lifetime ( $\tau_{\text {octane }} \approx 1$ day) compared to isoprene $\left(\tau_{\text {isoprene }} \approx 1.5 \mathrm{~h}\right.$ ). Adding deliquescent aerosols in the model has no impact on the carbon budget (not shown). However the addition of a water content representative of cloud conditions leads to a large organic content in the aqueous phase (see Fig. 1d). For these conditions, the secondary organic species first split equally in the gas and aqueous phases (for $N_{\tau}<2.5$ ). The functionalization of the carbon backbone by atmospheric processing leads progressively to species of increasing solubility and dissolved carbon prevails for $N_{\tau}>2.5$. The carbon atom ratio in the aqueous phase reaches a maximum of $55 \%$ at $N_{\tau}=13$ and next slowly declines with aging due to fragmentation of the carbon backbone by gas phase oxidation. At the end of the simulation $\left(N_{\tau}=20\right), 54 \%$ of initial carbon atoms are still in the aqueous phase. The production rate of $\mathrm{CO}+\mathrm{CO}_{2}$ is much slower in this case, most organic species being temporally trapped in condensed phase and therefore not subjected to oxidation in this version of the model.

The time evolution of the carbon atoms distribution during $\alpha$-pinene oxidation is given in Fig. 1e for dry conditions. Carbon distributions exhibit a behavior similar to the isoprene oxidation case. The simulated organic content in the deliquescent particle remains below $2 \%$ (not shown). Figure 1f shows that for $L$ set to a cloud value, a significant fraction of the carbon atoms is transferred into the aqueous phase. The majority of the initial carbon atoms are found in water ( $52 \%$ on a carbon basis) at the end of the simulation. Similar to the octane oxidation simulation, cloud water acts in this version of the model as an inert reservoir and slows down the $\mathrm{CO}+\mathrm{CO}_{2}$ formation. The $\mathrm{CO}+\mathrm{CO}_{2}$ fraction at $N_{\tau}=20$ decreases from $18 \%$ for the dry scenario to $11 \%$ for the cloud scenario.

The simulation results clearly show that most secondary organic species produced during the oxidation of aliphatic hydrocarbons are soluble enough to be dissolved in the aqueous phase during cloud events. This dissolved organic matter is then likely subject to a fast processing which may significantly shape the ultimate oxidation budget. This process is taken into account in some recent atmospheric chemical models using simplified parameterizations. For example the CMAQ model (Carlton et al., 2008) and the GEOSChem model (Fu et al., 2008, 2009) include SOA formation pathways through in-cloud oxidation of glyoxal and methylglyoxal, parameterized with laboratory experiments yields. However, these models cannot take into account the progressive nature of the oxidation process and the large number of different species involved in the formation of aqueous organic carbon. Our results show that the dissolution of long chain organic species has a significant contribution to the aqueous phase organic content and therefore should be accounted for in models.

The simulated organic content for aqueous aerosol conditions remains small for the three parent compounds considered in this study. However, we emphasize that the same uptake parameters are here applied for clouds and aerosols. Recent studies have shown that when aerosol water is not considered as a dilute solution and is modeled accordingly, SOA yields are higher than SOA yields from in-cloud oxidation (e.g. Ervens et al., 2011). This can arise from the effect of dissolved ions on equilibrium and uptake values (e.g. Ip et al., 2009) and from the effects of higher concentrations which allow the formation of higher molecular weight species (e.g. Ervens et al., 2011 and references therein). As the composition of the inorganic material on which the liquid phase 


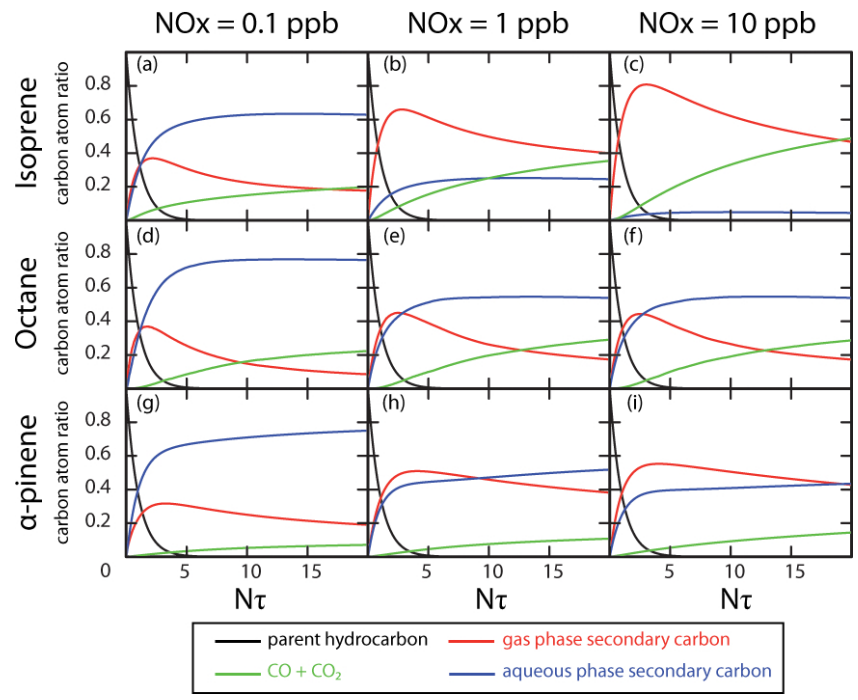

Fig. 2. Carbon budget during the oxidation of isoprene (top line), octane (middle line) and $\alpha$-pinene (bottom line) for a $\mathrm{NO}_{\mathrm{x}}$ concentration of $0.1 \mathrm{ppb}$ (1 $1 \mathrm{st}$ column), $1 \mathrm{ppb}$ (2nd column) and $10 \mathrm{ppb}$ (3rd column), with a cloud liquid water content $\left(L=3 \times 10^{-7}\right)$. The time scale is described in the text.

deliquesces is not simulated in the model, the effect of dissolved ions such as sulfate or chloride on uptake parameters cannot be represented. Our results show that under conditions typical of a deliquescent aerosol, SOA formation cannot be explained only by phase partitioning and aqueous phase processes have to be taken into account. Nevertheless, under cloud like conditions, the three precursors yield substantial amounts of condensed organic matter even if aqueous phase processes are ignored.

\subsection{Carbon budget and $\mathrm{NO}_{\mathrm{x}}$ conditions}

The Henry's law constant of an organic compound is linked to the functional groups on the carbon backbone as well as the length of the carbon skeleton (e.g. Raventos-Duran et al., 2010; Schwarzenbach et al., 2005). The nature and the number of organic moieties added to the carbon skeleton during atmospheric processing depend in particular on $\mathrm{NO}_{\mathrm{x}}$ concentration (e.g. Finlayson-Pitts and Pitts, 2000; Atkinson and Arey, 2003). Simulations were therefore conducted for various scenarios: low $\mathrm{NO}_{\mathrm{x}}$ conditions $(0.1 \mathrm{ppb})$, intermediate $\mathrm{NO}_{\mathrm{x}}$ conditions $(1 \mathrm{ppb})$ and high $\mathrm{NO}_{\mathrm{x}}$ conditions $(10 \mathrm{ppb})$. Figure 2 shows the results of these simulations for isoprene, octane and $\alpha$-pinene with a water content corresponding to cloud conditions. Note that modifications of the $\mathrm{NO}_{\mathrm{x}}$ conditions also impact on the concentrations of $\mathrm{OH}, \mathrm{O}_{3}$ and $\mathrm{NO}_{3}$. The relative contribution of these oxidants to oxidation of the precursors depends generally on $\mathrm{NO}_{\mathrm{x}}$ levels, especially for isoprene and $\alpha$-pinene. However, for all $\mathrm{NO}_{\mathrm{x}}$ conditions explored here, $\mathrm{OH}$ drives the oxidation of isoprene and both $\mathrm{OH}$ and $\mathrm{O}_{3}$ drive the oxidation $\alpha$-pinene during the first ox- idation steps. Therefore, $\mathrm{NO}_{\mathrm{x}}$ concentrations have an impact on secondary organics speciation mostly through the fate of peroxy radicals, rather than the initiation reactions.

Figure 2 shows that the dissolved organic content tends to increase with decreasing $\mathrm{NO}_{\mathrm{x}}$ concentration. The carbon atom ratio in the various phases appears to be especially sensitive to $\mathrm{NO}_{\mathrm{x}}$ for the isoprene simulation. For the 3 hydrocarbons examined in this study, the largest effects on carbon partitioning are seen at the lower $\mathrm{NO}_{\mathrm{x}}$ concentrations. At the end of the simulations, the fraction of dissolved aqueous carbon is increased by $39 \%$ for isoprene, $23 \%$ for octane and $23 \%$ for $\alpha$-pinene, from the intermediate to the low $\mathrm{NO}_{\mathrm{x}}$ scenario (Fig. 2a, d and g). The amount of dissolved organic carbon is reduced by $20 \%$ when $\mathrm{NO}_{\mathrm{x}}$ concentration is switched from intermediate to high $\mathrm{NO}_{\mathrm{x}}$ conditions in the isoprene case (see Fig. 2b and c).

\subsection{Functional groups in the gas and aqueous phase}

Figure 3a shows the distribution of the organic moieties of the simulated secondary organics at $N_{\tau}=2$ for the isoprene oxidation. The distribution is given for gas and aqueous phases, for the three $\mathrm{NO}_{\mathrm{x}}$ scenarios and for $L$ set to cloud conditions. Results are provided as the number of functional groups per carbon atom ratio $R_{\mathrm{OF} / \mathrm{C}}$, defined as:

$R_{\mathrm{OF} / \mathrm{C}}=\frac{\sum_{i} n_{i}^{\mathrm{OF}} C_{i}}{\sum_{i} n_{i}^{\mathrm{C}} C_{i}}$

where $\mathrm{OF}$ is a given organic function. $C_{i}$ is the concentration of species $i$ in the considered phase and $n_{i}^{\mathrm{OF}}$ or $n_{i}^{\mathrm{C}}$ are the number of organic function OF or carbon atoms in the species $i$, respectively. In the gas phase, the degree of substitution of the organics ranges from $28 \%$ (low $\mathrm{NO}_{\mathrm{x}}$ scenario) to $38 \%$ (high $\mathrm{NO}_{\mathrm{x}}$ scenario). The distribution is dominated by carbonyls for all $\mathrm{NO}_{\mathrm{x}}$ scenarios. The substitution degree is comparatively larger in the aqueous phase than in the gas phase and ranges from $45 \%$ (low $\mathrm{NO}_{\mathrm{x}}$ scenario) to $64 \%$ (high $\mathrm{NO}_{\mathrm{x}}$ scenario). The hydroxyl group is a major moiety in the aqueous phase (substitution degree in the 22-30\% range). Under low $\mathrm{NO}_{\mathrm{x}}$ conditions, the organic peroxy radical chemistry is dominated by $\mathrm{RO}_{2}+\mathrm{HO}_{2}$ reactions, leading to the formation of hydroperoxides ROOH. These hydroperoxides are major contributors to the aqueous phase organic content. Under high $\mathrm{NO}_{\mathrm{x}}$ conditions, the reaction $\mathrm{RO}_{2}+\mathrm{NO}$ dominates the evolution of peroxy radicals, leading among other things to the formation of the nitrate moiety. As expected, switching from low $\mathrm{NO}_{\mathrm{x}}$ to high $\mathrm{NO}_{\mathrm{x}}$ conditions makes the nitrate moiety grow at the expense of the hydroperoxide moiety (see Fig. 3a).

Figure $3 \mathrm{~b}$ gives the distribution of organic species as a function of chain length and the number of functional groups borne by the molecules for the isoprene simulations at $N_{\tau}=$ 2. The distribution is dominated by $\mathrm{C}_{4}$ species in the gas 

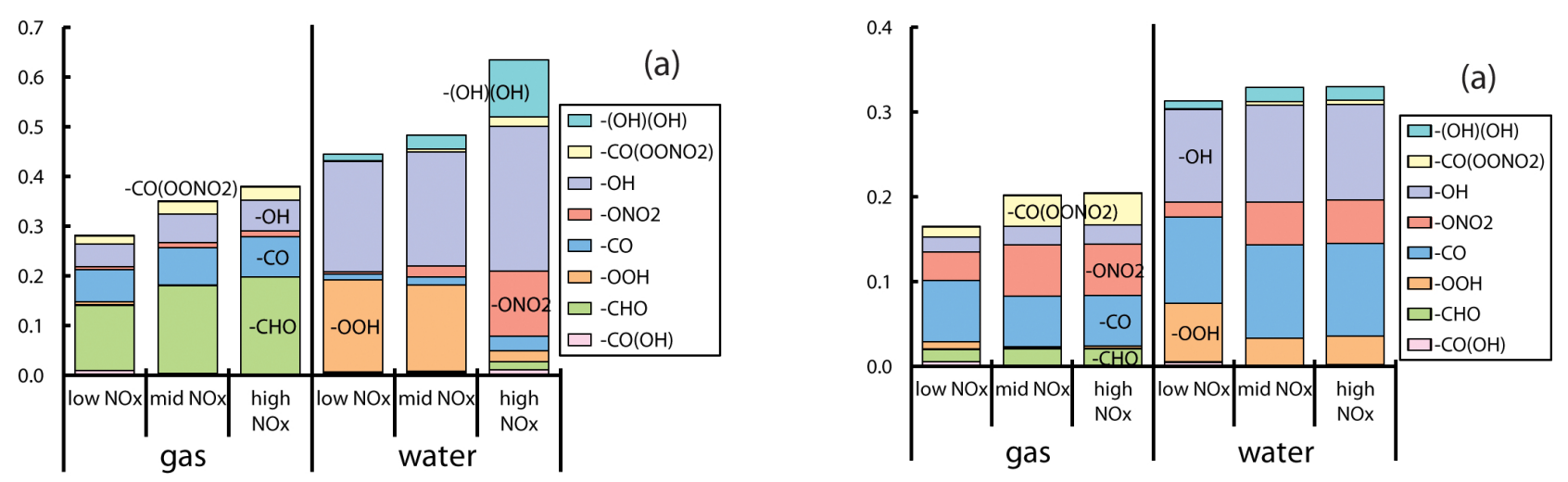

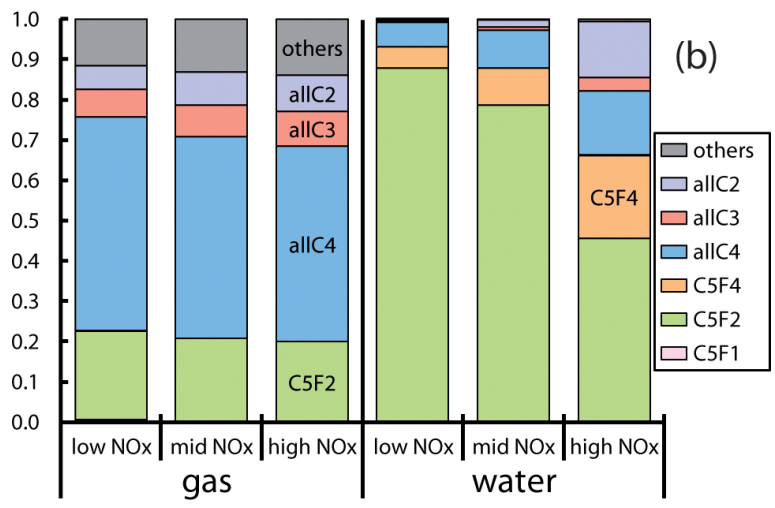

Fig. 3. At $N_{\tau}=2$, simulated distribution in gaseous and aqueous phase of organic moieties ratio $\left(R_{\mathrm{OF} / \mathrm{C}}\right.$, panel a) and functionalization (panel $\mathbf{b}$ ) for a cloud water content during the oxidation of isoprene. $\mathrm{C} m \mathrm{~F} n$ category merges species with $m$ carbon atoms bearing $n$ functional groups. The precursor and $\mathrm{C}_{1}$ species are lumped in the others category.

phase, mainly methyl vinyl ketone and methacrolein. In the aqueous phase, the distribution is dominated by $\mathrm{C}_{5}$ species bearing two functional groups, i.e. hydroxy-hydroperoxides species under low $\mathrm{NO}_{\mathrm{x}}$ conditions and hydroxy-nitrate or hydroxy-carbonyl species under high $\mathrm{NO}_{\mathrm{x}}$ conditions. Under high $\mathrm{NO}_{\mathrm{x}}$ conditions, quadrifunctional $\mathrm{C}_{5}$ and $\mathrm{C}_{4}$ species contribute also substantially ( $11 \%)$ to the organic content of the aqueous phase.

Figure 4 shows the distribution of organic moieties (panel a) and the distribution as a function of chain length and number of functional groups (panel $b$ ) for the octane simulations at $N_{\tau}=2$. The substitution degree ranges from $16-20 \%$ in the gas phase to $31-33 \%$ in the aqueous phase. The distribution is dominated by $\mathrm{C}_{8}$ species bearing one or two functional groups in the gas phase and two or three functional groups in the aqueous phase. The gas phase distribution is dominated by the carbonyl moieties, with a substantial contribution of nitrate moieties under high $\mathrm{NO}_{\mathrm{x}}$ conditions. In the aqueous phase, about $21 \%$ of the carbon atoms are substituted either by a hydroxy or a carbonyl moiety (see Fig. 4a). As expected, hydroperoxide is a significant func- tional group under low $\mathrm{NO}_{\mathrm{x}}\left(R_{-\mathrm{OOH} / \mathrm{C}}=7 \%\right)$ while nitrate is substantial under high $\mathrm{NO}_{\mathrm{x}}\left(R_{-\mathrm{ONO}_{2} / \mathrm{C}}=5 \%\right)$.

Figure 5 shows the distribution of the functional groups for the $\alpha$-pinene simulations. Molecules are functionalized with a substitution degree ranging from $16 \%$ in the gas phase to $25 \%$ in the aqueous phase. Difunctional $C_{10}$ species dominate both the gas phase and the aqueous phase distribution (60 to $70 \%$ of the carbon atom ratio in each phase). In the gas phase, $\mathrm{C}_{9}$ and $\mathrm{C}_{8}$ contribute substantially to the carbon budget (18-23\%). In the aqueous phase, trifunctional $\mathrm{C}_{10}$ contribute also substantially to the carbon budget (22-28\%). The gas phase is mainly composed of carbonyl compounds $\left(R_{>} \mathrm{CO} / \mathrm{C}=11 \%\right.$ under intermediate $\mathrm{NO}_{\mathrm{x}}$ conditions). Nitrates $\left(R_{-\mathrm{ONO}_{2} / \mathrm{C}}=2.5 \%\right)$, hydroxyl $\left(R_{-\mathrm{OH} / \mathrm{C}}=1.9 \%\right)$ and PAN $\left(R_{-\mathrm{CO}\left(\mathrm{OONO}_{2}\right) / \mathrm{C}}=2.3 \%\right)$ moieties contribute to a lesser extent to the gas phase composition. In the aqueous phase, the main contributors to the global functionalization are (hydrated) carbonyls $\left(R_{>} \mathrm{CO} / \mathrm{C}+\right.$ $R_{-\mathrm{C}(\mathrm{OH})(\mathrm{OH}) / \mathrm{C}}=16 \%$ under high $\mathrm{NO}_{\mathrm{x}}$ conditions). The simulated substitution degree by carboxylic acids and their associated bases $\left(R_{-\mathrm{CO}(\mathrm{OH}) / \mathrm{C}}+R_{-\mathrm{CO}(\mathrm{O}-) / \mathrm{C})}\right.$ is $2.6 \%$, a 

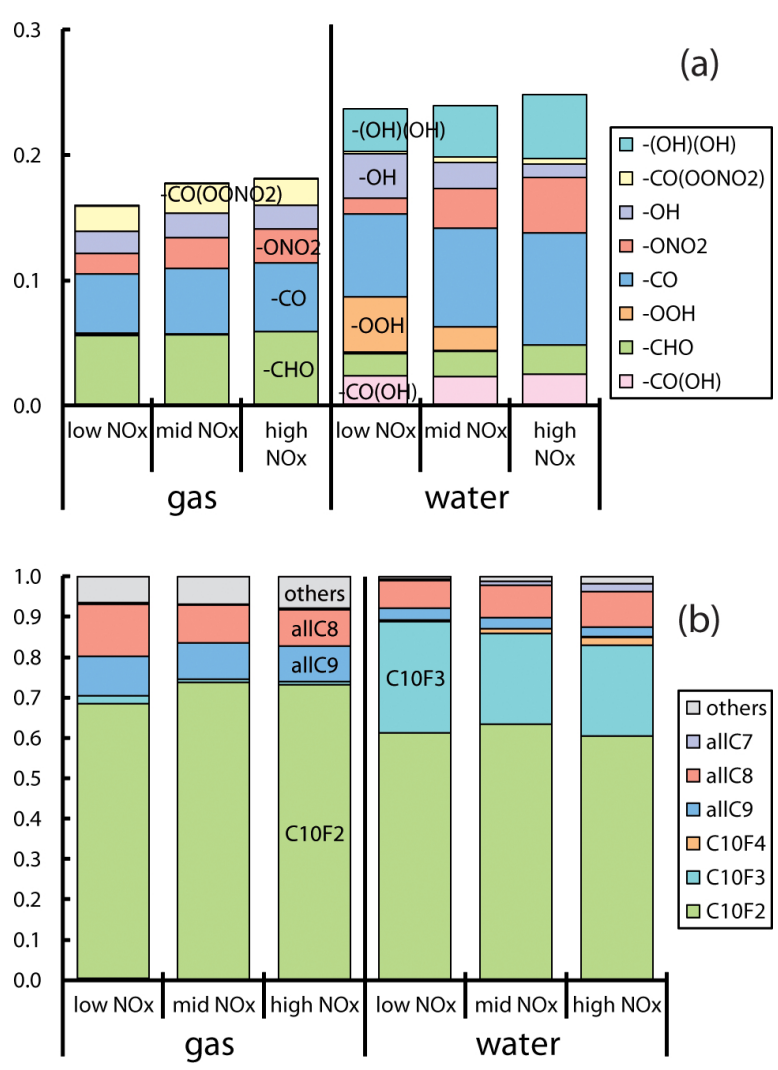

Fig. 5. At $N_{\tau}=2$, simulated distribution in gaseous and aqueous phase of organic moieties ratio $\left(R_{\mathrm{OF} / \mathrm{C}}\right.$, panel a) and functionalization (panel b) for a cloud water content during the oxidation of $\alpha$-pinene. $\mathrm{C} m \mathrm{~F} n$ category merges species with $m$ carbon atoms bearing $n$ functional groups. The precursor and $\mathrm{C}_{1}-\mathrm{C}_{6}$ species are lumped in the others category.

value that corroborates the fact that no significant source of organic acids is identified in the gas phase, hence their small representation in the dissolved organic content (Aumont et al., 2000). Nitrates are significant under high $\mathrm{NO}_{\mathrm{x}}$ $\left(R_{-\mathrm{ONO} 2 / \mathrm{C}}=4.4 \%\right)$ while hydroperoxydes have an important contribution under low $\mathrm{NO}_{\mathrm{x}}$ conditions $\left(R_{-\mathrm{OOH} / \mathrm{C}}=\right.$ $4.5 \%)$.

\subsection{Oxidative trajectories in an oxidation state vs. solubility framework}

The gas phase oxidation of the organic species includes competitive processes leading either to the functionalization of the carbon backbone or to its fragmentation. The progressive functionalization of the carbon skeleton may lead to species with low enough volatility to condense. Conversely, fragmentation of the carbon skeleton leads to species with higher volatilities and ultimately to $\mathrm{CO}_{2}$. In the context of organic partitioning between gas and aqueous phases, functionalization routes progressively increase the Henry's law coefficient of the species and therefore favor partitioning to the aqueous phase (e.g. Schwarzenbach et al., 2005; Raventos-Duran et al., 2010). The opposite behavior is usually noticed for the fragmentation routes. For example, Fig. 3 shows that for isoprene in all $\mathrm{NO}_{\mathrm{x}}$ configurations, functionalized $\mathrm{C}_{5}$ species are mostly found in water whereas fragmented $\mathrm{C}_{<5}$ species tend to be preferentially found in the gas phase. Figure 4 (Fig. 5) shows that it is also true for octane ( $\alpha$-pinene) where the proportion of functionalized $\mathrm{C}_{8}\left(\mathrm{C}_{10}\right)$ species is larger in the aqueous phase and the proportion of fragmented $\mathrm{C}_{<8}$ $\left(\mathrm{C}_{<10}\right)$ species is larger in the gas phase.

Two dimensional frameworks have been recently proposed to examine the formation and aging of secondary organic aerosols during atmospheric oxidation of hydrocarbons (e.g. Jimenez et al., 2009; Pankow and Barsanti, 2009; Barsanti et al., 2011; Kroll et al., 2011). These frameworks attempt to capture the oxidative trajectories in a space defined by the volatility of the secondary species and their oxidation degree (e.g. Donahue et al., 2011, 2012). A similar two dimensional frameworks is used here to explore the oxidative trajectories in the context of a gas/aqueous multiphase system. We define the first dimension by the Henry's law coefficient $H$, used as a metric to represent the water solubility of the species. With $L=3 \times 10^{-7}$, a species is equally distributed in the two phases $(\xi=0.5)$ for $H=1.45 \times 10^{5} \mathrm{Matm}^{-1}$ (see Eq. 1). Species having $H$ less than $1.45 \times 10^{3} \mathrm{M} \mathrm{atm}^{-1}$ will therefore almost exclusively be found in the gas phase $(\xi<0.01)$, while species with $H$ greater than $1.45 \times 10^{7} \mathrm{M} \mathrm{atm}^{-1}$ will almost exclusively be found in the aqueous phase $(\xi>0.99)$. We use the mean carbon oxidation $\left(\overline{\mathrm{OS}}_{\mathrm{C}}\right)$ as the second dimension. In this framework, the parent hydrocarbon is placed at the bottom of the graph and the ending point of the oxidative trajectories $\left(\mathrm{CO}_{2}\right)$ is placed at the top left $\left(\overline{\mathrm{OS}}_{\mathrm{C}}=4\right)$.

Figure 6 shows the distribution of species produced during the gas phase oxidation of isoprene in this solubility/ $\overline{\mathrm{OS}}_{\mathrm{C}}$ space for 4 different times $\left(N_{\tau}=0,1,2,10\right)$. Distributions are shown for the $3 \mathrm{NO}_{\mathrm{x}}$ scenarios. The carbon atom ratio of a given species is proportional to the volume of the bubble. Species contributing for less than $10^{-4}$ to the total carbon are not shown for clarity. The SAR used to estimate $H$ (Raventos-Duran et al., 2010) provides identical values for distinct position isomers. Position isomers with identical $H$ are lumped to avoid overlap of the bubbles. In Fig. 6, species with a carbon backbone identical to the parent compound (blue bubbles) delineate the functionalization route. Species with a smaller backbone (orange bubbles) delineate trajectories including at least one fragmentation in the oxidation steps.

As expected, the first step of the isoprene oxidation is dominated by fragmentation routes (see Fig. 6). Under high $\mathrm{NO}_{\mathrm{x}}$ conditions, oxidation leads mostly to species with $H$ in the $10^{0}-10^{4} \mathrm{M} \mathrm{atm}^{-1}$ range, i.e. low enough to be mostly distributed in the gas phase at thermodynamic equilibrium. At $N_{\tau}=10,10$ species contribute for $90 \%$ of the carbon budget. These species are the expected major isoprene oxidation products, as shown in Table 2. Under low $\mathrm{NO}_{\mathrm{x}}$ 


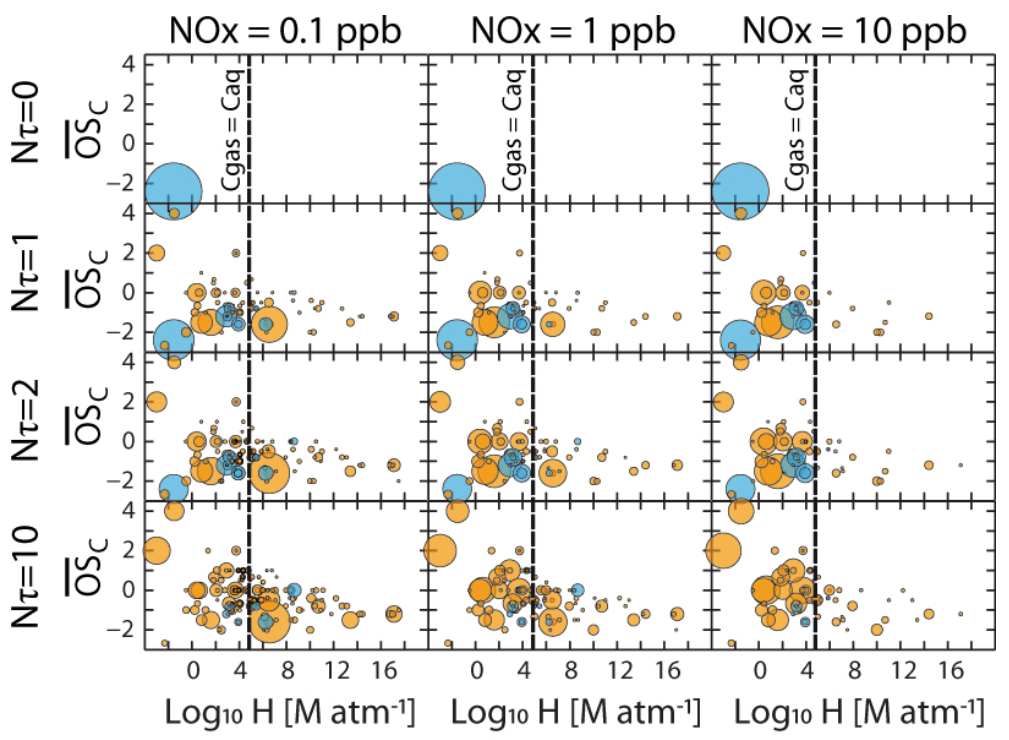

$\bigcirc=1 \bigcirc=0.5 \bigcirc=0.1 \circ=0.01$

Fig. 6. Solubility and mean oxidation state of the species produced during the oxidation of isoprene under low $\mathrm{NO}_{\mathrm{x}}(1 \mathrm{st}$ column), intermediate $\mathrm{NO}_{\mathrm{x}}\left(2 \mathrm{nd}\right.$ column) and high $\mathrm{NO}_{\mathrm{x}}$ (3rd column) conditions as a function of the number of precursor lifetime. Contribution of a species to the global carbon budget is proportional to the volume of the bubble. Position isomers having identical solubility and oxidation state are lumped in the same bubble. Blue bubbles denote species having the carbon skeleton of the parent hydrocarbon. Orange bubbles denote species with less carbon atoms than the parent compound. The black dashed lines denote the solubility for which a compound is equally distributed in the aqueous and gaseous phases.

conditions, the solubility distribution spans more than 10 orders of magnitude. At $N_{\tau}=10$, the carbon distribution is shifted to higher values of solubility. Therefore, the carbon atom fraction in the aqueous phase is substantial, reaching $63 \%$ at $N_{\tau}=10$ (see Fig. 2i). The major contributors to the aqueous organic composition are an hydroxy-hydroperoxyde $\left(\mathrm{CH}_{3} \mathrm{C}(\mathrm{OOH})\left(\mathrm{CH}_{2}(\mathrm{OH})\right) \mathrm{CH}=\mathrm{CH}_{2}\right)$ and its position isomers.

Figure 7 shows that the octane oxidation is first dominated by the functionalization routes and as oxidation proceeds fragmentation routes become substantial. Species are distributed in a broader range of solubility, at first in the $10^{-3}-10^{8} \mathrm{M} \mathrm{atm}^{-1}$ range and then in the $10^{1}-10^{12} \mathrm{M} \mathrm{atm}^{-1}$ range after the first oxidation steps. Thus species are at first evenly distributed in both phases and become more prevalent in the aqueous phase after $N_{\tau}=2$ (see also Fig. 2). At $N_{\tau}=10,60 \%$ of the gaseous carbon can be ascribed to 10 species, peroxy acetyl nitrate and peroxy propyl nitrate being the major species, as seen in Table 2. Under low $\mathrm{NO}_{\mathrm{x}}$ conditions, the solubility distribution range is approximately the same, but more species are on the high solubility range $\left(H>7 \times 10^{6} \mathrm{M} \mathrm{atm}^{-1}\right)$. The fraction of dissolved carbon reaches $77 \%$ at $N_{\tau}=10$.

Like isoprene, $\alpha$-pinene oxidation is dominated by fragmentation (see Fig. 8). H-values for most species fall in the $10^{5}-10^{13} \mathrm{M} \mathrm{atm}^{-1}$ range, i.e. partition in the aqueous phase at thermodynamic equilibrium. In the gas phase, a difunctional $\mathrm{C}_{10}$ PAN-like species is dominant, followed by acetone, formaldehyde and PAN (see Table 2). As expected from the species solubility range, dissolved carbon represents $71 \%$ of the total carbon in low $\mathrm{NO}_{\mathrm{x}}$ conditions at $N_{\tau}=10$.

\section{Conclusions}

Explicit gaseous oxidation schemes have been generated for three precursors of atmospheric interest (isoprene, octane, $\alpha$ pinene) using GECKO-A. The partitioning of the secondary organic compounds between gaseous and aqueous phases has been examined for a liquid water content corresponding to clouds and deliquescent aerosols. For $L=1 \times 10^{-12}$ (i.e. aerosols water), only a small fraction of the secondary organic carbon is influenced by the aqueous phase. Note that this small partitioning toward the aqueous phase might be offset by chemical sinks in the condensed phase which were ignored in our model configuration (e.g. Surratt et al., 2010; McNeill et al., 2012). For $L=3 \times 10^{-7}$ (i.e. cloud water), the phase distribution of organic carbon is sensitive to $\mathrm{NO}_{\mathrm{x}}$ concentrations. For low $\mathrm{NO}_{\mathrm{x}}$ conditions, $50 \%$ (isoprene oxidation) to $70 \%$ (octane oxidation) of the carbon atoms are found in the aqueous phase after the removal of the parent compound $\left(N_{\tau} \approx 3\right)$. For high $\mathrm{NO}_{\mathrm{x}}$ condition, this ratio is only $5 \%$ in the isoprene oxidation case, but remains large for 


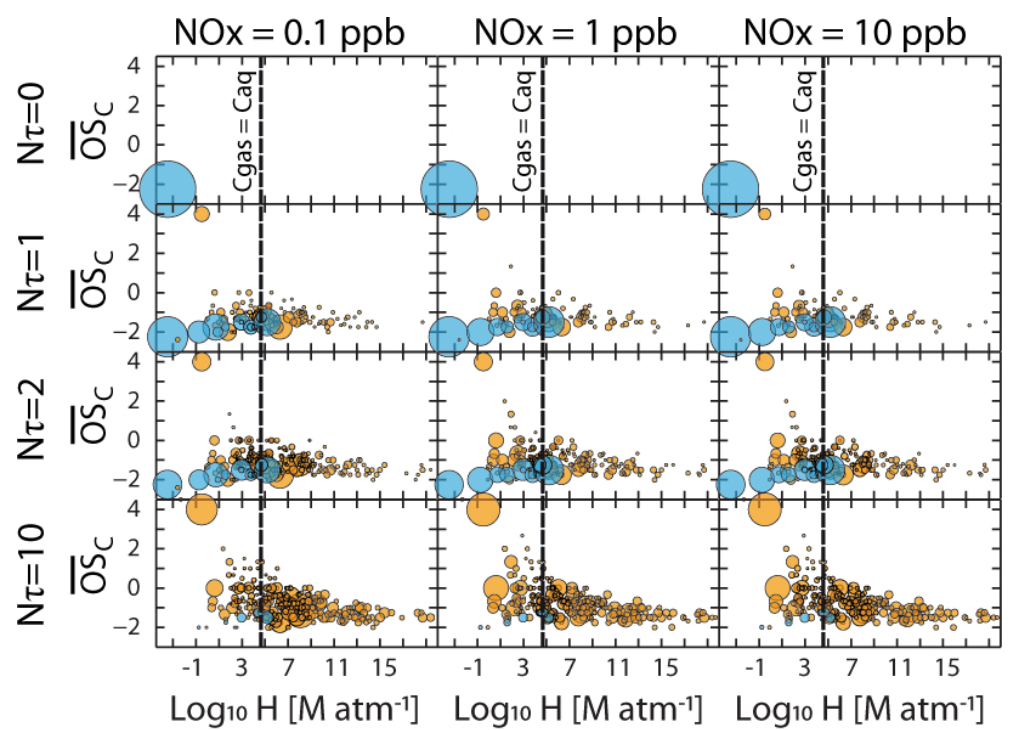

$$
\bigcirc=1 \bigcirc=0.5 \bigcirc=0.1 \circ=0.01
$$

Fig. 7. Solubility and mean oxidation state of the species produced during the oxidation of octane under low $\mathrm{NO}_{\mathrm{x}}(1 \mathrm{st}$ column), intermediate $\mathrm{NO}_{\mathrm{x}}(2 \mathrm{nd}$ column$)$ and high $\mathrm{NO}_{\mathrm{x}}$ (3rd column) conditions as a function of the number of precursor lifetime. See Fig. 6 caption for the color code of the bubbles.

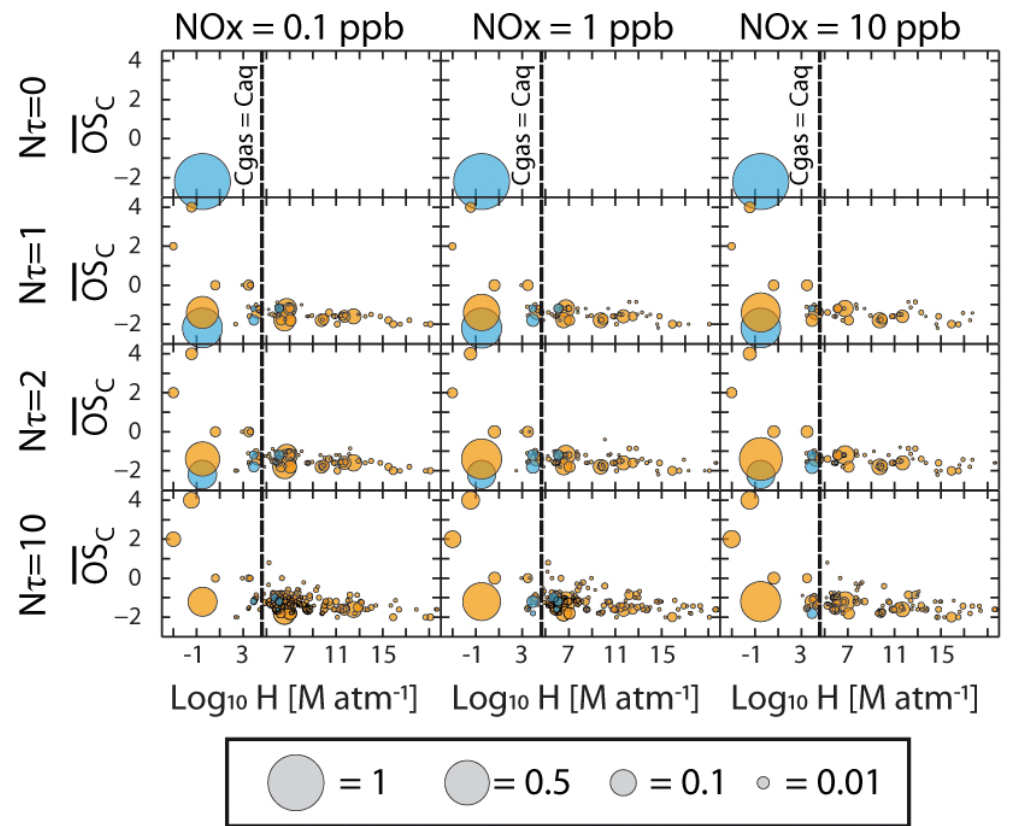

Fig. 8. Solubility and mean oxidation state of the species produced during the oxidation of $\alpha$-pinene under low $\mathrm{NO}_{\mathrm{x}}(1 \mathrm{st}$ column), intermediate $\mathrm{NO}_{\mathrm{x}}\left(2 \mathrm{nd}\right.$ column) and high $\mathrm{NO}_{\mathrm{x}}(3 \mathrm{rd}$ column) conditions as a function of the number of precursor lifetime. See Fig. 6 caption for the color code of the bubbles. 
Table 2. Top ten species simulated in gas and aqueous phase for a cloud liquid water content and for intermediate $\mathrm{NO}_{\mathrm{x}}$ conditions at $N_{\tau}=10$.

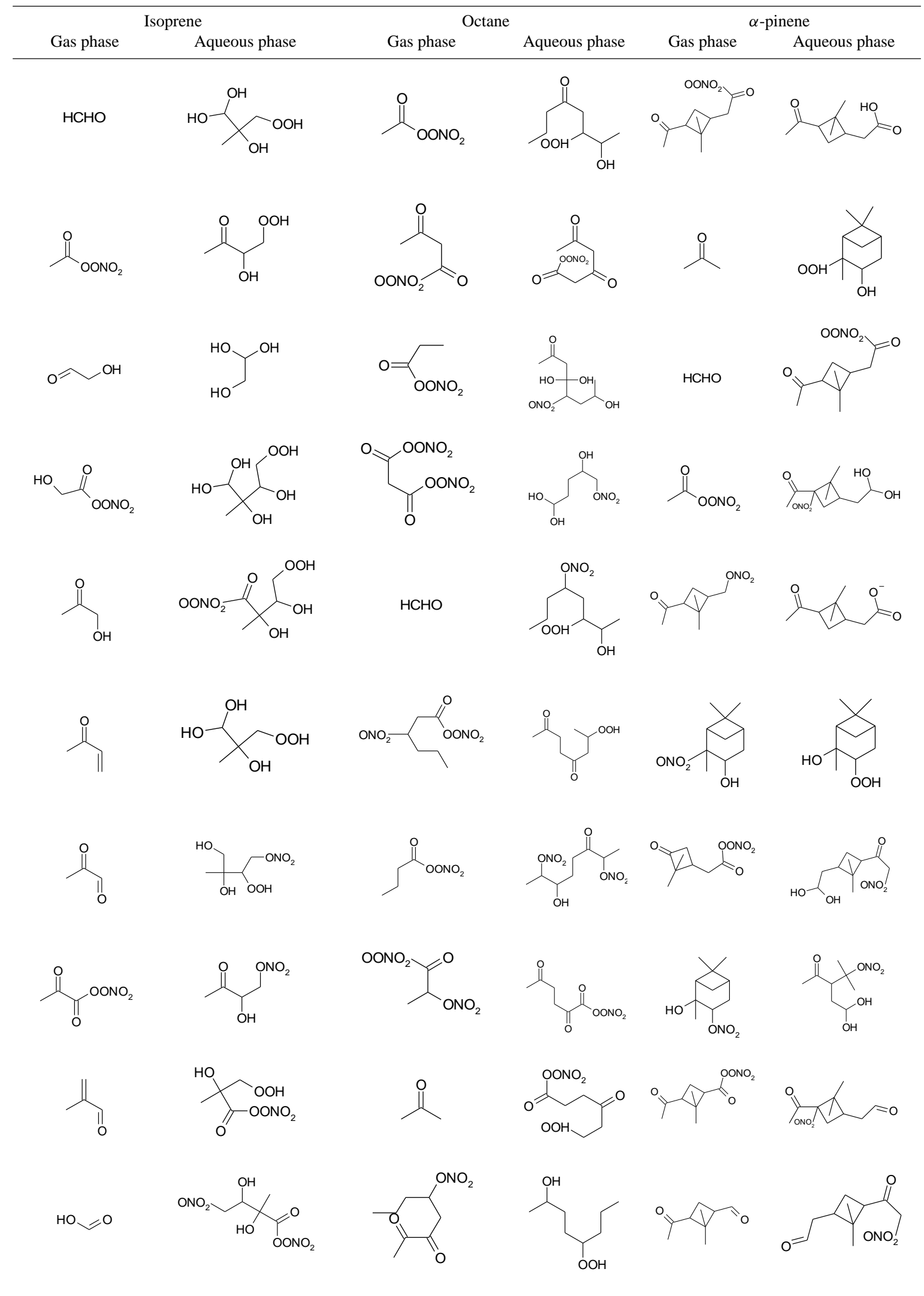


$\alpha$-pinene and octane oxidation cases (40\% and $60 \%$, respectively). This study therefore suggests that most secondary organic species produced during the multigenerational oxidation of anthropogenic and biogenic hydrocarbons should dissolve in the aqueous phase during cloud events.

The simulated oxidative trajectories are examined in a new two dimensional space defined by the mean oxidation state and the water solubility. Isoprene oxidation is dominated by fragmentation routes. The solubility distribution of the isoprene oxidation products appears to be especially sensitive to $\mathrm{NO}_{\mathrm{x}}$, with low $\mathrm{NO}_{\mathrm{x}}$ conditions favoring the production of more water soluble species. As a result, the fraction of dissolved carbon decreases from low to high $\mathrm{NO}_{\mathrm{x}}$ conditions. Octane oxidation is first dominated by functionalization routes, next by fragmentation routes, producing highly soluble species in both low $\mathrm{NO}_{\mathrm{x}}$ and high $\mathrm{NO}_{\mathrm{x}}$ conditions. The fragmentation routes dominate the $\alpha$-pinene oxidation pathways and lead to highly water soluble species whatever the $\mathrm{NO}_{\mathrm{x}}$ conditions are.

Once dissolved, organic species follow complex oxidation mechanisms. This study shows that during cloud events, a large fraction of organic matter could be processed in the aqueous phase and modify both the rates of reaction and the identity of their products. To the best of our knowledge, this process is currently ignored in current atmospheric chemical models dealing with the oxidation of long chain organics. To explore the contribution of these cloud processes, aqueous oxidation mechanisms are needed for the very large set of species expected to be significantly dissolved in the cloud droplets. Protocols are required to generate consistent and comprehensive aqueous oxidation schemes on a systematic basis. This is the object of ongoing studies.

Acknowledgements. This work was funded by the French-German Joint Research Program in Atmospheric Chemistry. The study has been performed in the frame of the "programme PRIMEQUAL" of the French Ministry of Ecology, Sustainable Development and Energy.

\section{Edited by: V. F. McNeill}

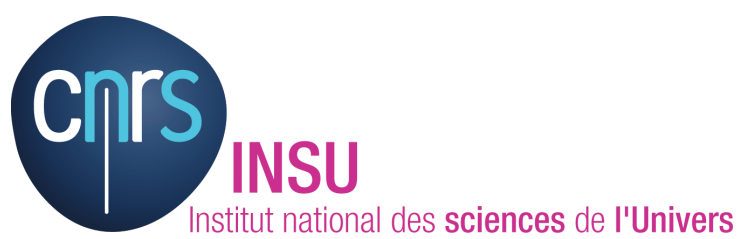

The publication of this article is financed by CNRS-INSU.

\section{References}

Altieri, K. E., Seitzinger, S. P., Carlton, A. G., Turpin, B. J., Klein, G. C., and Marshall, A. G.: Oligomers formed through in-cloud methylglyoxal reactions: Chemical composition, properties, and mechanisms investigated by ultra-high resolution FT-ICR mass spectrometry, Atmos. Environ., 42, 1476-1490, 2008.

Atkinson, R. and Arey, J.: Atmospheric degradation of volatile organic compounds, Chem. Rev., 103, 4605-4638, 2003.

Aumont, B., Madronich, S., Bey, I., and Tyndall, G. S.: Contribution of secondary voc to the composition of aqueous atmospheric particles: a modeling approach, J. Atmos. Chem., 35, 59-75, 2000.

Aumont, B., Szopa, S., and Madronich, S.: Modelling the evolution of organic carbon during its gas-phase tropospheric oxidation: development of an explicit model based on a self generating approach, Atmos. Chem. Phys., 5, 2497-2517, doi:10.5194/acp-52497-2005, 2005.

Aumont, B., Valorso, R., Mouchel-Vallon, C., Camredon, M., LeeTaylor, J., and Madronich, S.: Modeling SOA formation from the oxidation of intermediate volatility $n$-alkanes, Atmos. Chem. Phys., 12, 7577-7589, doi:10.5194/acp-12-7577-2012, 2012.

Barth, M. C., Sillman, S., Hudman, R., Jacobson, M. Z., Kim, C. H., Monod, A., and Liang, J.: Summary of the cloud chemistry modeling intercomparison: photochemical box model simulation, J. Geophys. Res.-Atmos., 108, 4214, doi:10.1029/2002JD002673, 2003.

Barsanti, K. C., Smith, J. N., and Pankow, J. F.: Application of the $\mathrm{np}$ plus $\mathrm{mP}$ modeling approach for simulating secondary organic particulate matter formation from alpha-pinene oxidation, Atmos. Environ., 45, 6812-6819, 2011.

Bateman, A. P., Nizkorodov, S. A., Laskin, J. and Laskin, A.: Photolytic processing of secondary organic aerosols dissolved in cloud droplets, Phys. Chem. Chem. Phys., 13, 12199-12212, 2011.

Brüggemann, E., Gnauk, T., Mertes, S., Acker, K., Auel, R., Wieprecht, W., Möller, D., Collett, J. L., Chang, H., Galgon, D., Chemnitzer, R., Rüd, C., Junek, R., Wiedensohler, W., and Herrmann, H.: Schmücke hill cap cloud and valley stations aerosol characterisation during FEBUKO (I): Particle size distribution, mass, and main components, Atmos. Environ., 39, 4291-4303, doi:10.1016/j.atmosenv.2005.02.013, 2005.

Camredon, M., Aumont, B., Lee-Taylor, J., and Madronich, S.: The SOA/VOC/NO $\mathrm{NO}_{\mathrm{x}}$ system: an explicit model of secondary organic aerosol formation, Atmos. Chem. Phys., 7, 5599-5610, doi:10.5194/acp-7-5599-2007, 2007.

Carlton, A. G., Turpin, B. I., Altieri, K. E., Seitzinger, S. P., Mathur, R., Roselle, S. J., and Weber, R. J.: CMAQ model performance enhanced when in-cloud secondary organic aerosol is included: comparisons of organic carbon predictions with measurements, Environ. Sci. Technol., 42, 8798-8802, 2008.

Carlton, A. G., Wiedinmyer, C., and Kroll, J. H.: A review of Secondary Organic Aerosol (SOA) formation from isoprene, Atmos. Chem. Phys., 9, 4987-5005, doi:10.5194/acp-9-4987-2009, 2009.

Chebbi, A. and Carlier, P.: Carboxylic acids in the troposphere, occurrence, sources, and sinks: A review, Atmos. Environ., 30, 4233-4249, 1996.

Crahan, K. K., Hegg, D., Covert, D. S., and Jonsson, H.: An exploration of aqueous oxalic acid production in the coastal marine atmosphere, Atmos. Environ., 38, 3757-3764, 2004. 
Davidovits, P., Hu, J. H., Worsnop, D. R., Zahniser, M. S., and Kolb, C. E.: Entry of gas molecules into liquids, Faraday Discuss., 100, 65-81, 1995.

Davidovits, P., Kolb, C. E., Williams, L. R., Jayne, J. T., and Worsnop, D. R.: Update 1 of: mass accommodation and chemical reactions at gas-liquid interfaces, Chem. Rev., 111, PR76PR109, 2011.

Donahue, N. M., Epstein, S. A., Pandis, S. N., and Robinson, A. L.: A two-dimensional volatility basis set: 1. organic-aerosol mixing thermodynamics, Atmos. Chem. Phys., 11, 3303-3318, doi:10.5194/acp-11-3303-2011, 2011.

Donahue, N. M., Kroll, J. H., Pandis, S. N., and Robinson, A. L.: A two-dimensional volatility basis set - Part 2: Diagnostics of organic-aerosol evolution, Atmos. Chem. Phys., 12, 615-634, doi:10.5194/acp-12-615-2012, 2012.

El Haddad, I., Yao Liu, Nieto-Gligorovski, L., Michaud, V., Temime-Roussel, B., Quivet, E., Marchand, N., Sellegri, K., and Monod, A.: In-cloud processes of methacrolein under simulated conditions - Part 2: Formation of secondary organic aerosol, Atmos. Chem. Phys., 9, 5107-5117, doi:10.5194/acp-9-5107-2009, 2009.

Engelhart, G. J., Hildebrandt, L., Kostenidou, E., Mihalopoulos, N., Donahue, N. M., and Pandis, S. N.: Water content of aged aerosol, Atmos. Chem. Phys., 11, 911-920, doi:10.5194/acp-11911-2011, 2011.

Ervens, B. and Volkamer, R.: Glyoxal processing by aerosol multiphase chemistry: towards a kinetic modeling framework of secondary organic aerosol formation in aqueous particles, Atmos. Chem. Phys., 10, 8219-8244, doi:10.5194/acp-10-8219-2010, 2010.

Ervens, B., Carlton, A. G., Turpin, B. J., Altieri, K. E., Kreidenweis, S. M., and Feingold, G.: Secondary organic aerosol yields from cloud-processing of isoprene oxidation products, Geophys. Res. Lett., 35, L02816, doi:10.1029/2007GL031828, 2008.

Ervens, B., Turpin, B. J., and Weber, R. J.: Secondary organic aerosol formation in cloud droplets and aqueous particles (aqSOA): a review of laboratory, field and model studies, Atmos. Chem. Phys., 11, 11069-11102, doi:10.5194/acp-1111069-2011, 2011.

Finlayson-Pitts, B. J. and Pitts, J. N.: Chemistry of the upper and lower atmosphere, Academic Press, San Diego, 2000.

Fu, T.-M., Jacob, D. J., Wittrock, F., Burrows, J. P., Vrekoussis, M., and Henze, D. K.: Global budgets of atmospheric glyoxal and methylglyoxal, and implications for formation of secondary organic aerosols, J. Geophys. Res.-Atmos., 113, D15303, doi:10.1029/2007JD009505, 2008.

$\mathrm{Fu}$, T., Jacob, D. J., and Heald, C. L.: Aqueous-phase reactive uptake of dicarbonyls as a source of organic aerosol over eastern north america, Atmos. Environ., 43, 1814-1822, 2009.

Hallquist, M., Wenger, J. C., Baltensperger, U., Rudich, Y., Simpson, D., Claeys, M., Dommen, J., Donahue, N. M., George, C., Goldstein, A. H., Hamilton, J. F., Herrmann, H., Hoffmann, T., Iinuma, Y., Jang, M., Jenkin, M. E., Jimenez, J. L., Kiendler-Scharr, A., Maenhaut, W., McFiggans, G., Mentel, Th. F., Monod, A., Prévôt, A. S. H., Seinfeld, J. H., Surratt, J. D., Szmigielski, R., and Wildt, J.: The formation, properties and impact of secondary organic aerosol: current and emerging issues, Atmos. Chem. Phys., 9, 5155-5236, doi:10.5194/acp-9-51552009, 2009.
Herrmann, H.: Kinetics of aqueous phase reactions relevant for atmospheric chemistry, Chem. Rev., 103, 4691-4716, 2003.

Herrmann, H., Wolke, R., Muller, K., Bruggemann, E., Gnauk, T., Barzaghi, P., Mertes, S., Lehmann, K., Massling, A., Birmili, W., Wiedensohler, A., Wierprecht, W., Acker, K., Jaeschke, W. Kramberger, H., Svrcina, B., Bachmann, K., Collett, J. L., Galgon, D., Schwirn, K., Nowak, A., van Pinxteren, D., Plewka, A., Chemnitzer, R., Rud, C., Hofmann, D., Tilgner, A., Diehl, K., Heinold, B., Hinneburg, D., Knoth, O., Sehili, A. M., Simmel, M., Wurzler, S., Majdik, Z., Mauersberger, G., and Muller, F.: Febuko and modmep: field measurements and modelling of aerosol and cloud multiphase processes, Atmos. Environ., 39, 4169-4183, 2005.

Ip, H. S. S., Huang, X. H. H., and Yu, J. Z.: Effective Henry's law constants of glyoxal, glyoxylic acid, and glycolic acid, Geophys. Res. Lett., 36, 1-5, doi:10.1029/2008GL036212, 2009.

Ivanov, A. V., Trakhtenberg, S., Bertram, A. K., Gershenzon, Y. M., and Molina, M. J.: OH, $\mathrm{HO}_{2}$, and Ozone Gaseous Diffusion Coefficients, J. Phys. Chem. A, 111, 1632-1637, 2007.

Jacob, D. J.: Chemistry of oh in remote clouds and its role in the production of formic-acid and peroxymonosulfate, J. Geophys. Res.-Atmos., 91, 9807-9826, 1986.

Jimenez, J. L., Canagaratna, M. R., Donahue, N. M., Prevot, A. S. H., Zhang, Q., Kroll, J. H., DeCarlo, P. F., Allan, J. D., Coe, H., Ng, N. L., Aiken, A. C., Docherty, K. S., Ulbrich, I. M., Grieshop, A. P., Robinson, A. L., Duplissy, J., Smith, J. D., Wilson, K. R., Lanz, V. A., Hueglin, C., Sun, Y. L., Tian, J., Laaksonen, A., Raatikainen, T., Rautiainen, J., Vaattovaara, P., Ehn, M., Kulmala, M., Tomlinson, J. M., Collins, D. R., Cubison, M. J., Dunlea, E. J., Huffman, J. A., Onasch, T. B., Alfarra, M. R., Williams, P. I., Bower, K., Kondo, Y., Schneider, J., Drewnick, F., Borrmann, S., Weimer, S., Demerjian, K., Salcedo, D., Cottrell, L., Griffin, R., Takami, A., Miyoshi, T., Hatakeyama, S., Shimono, A., Sun, J. Y., Zhang, Y. M., Dzepina, K., Kimmel, J. R., Sueper, D., Jayne, J. T., Herndon, S. C., Trimborn, A. M., Williams, L. R., Wood, E. C., Middlebrook, A. M., Kolb, C. E., Baltensperger, U., and Worsnop, D. R.: Evolution of organic aerosols in the atmosphere, Science, 326, 1525-1529, 2009.

Kreidenweis, S. M., Walcek, C. J., Feingold, G., Gong, W. M., Jacobson, M. Z., Kim, C. H., Liu, X. H., Penner, J. E., Nenes, A., and Seinfeld, J. H.: Modification of aerosol mass and size distribution due to aqueous-phase $\mathrm{SO}_{2}$ oxidation in clouds: comparisons of several models, J. Geophys. Res.-Atmos., 108, 4213, doi:10.1029/2002JD002697, 2003.

Kroll, J. H., Donahue, N. M., Jimenez, J. L., Kessler, S. H., Canagaratna, M. R., Wilson, K. R., Altieri, K. E., Mazzoleni, L.R., Wozniak, A. S., Bluhm, H., Mysak, E. R., Smith, J. D., Kolb, C. E., and Worsnop, D. R.: Carbon oxidation state as a metric for describing the chemistry of atmospheric organic aerosol, Nature Chem., 3, 133-139, 2011.

Kuhne, R., Ebert, R. U., and Schuurmann, G.: Prediction of the temperature dependency of henry's law constant from chemical structure, Environ. Sci. Technol., 39, 6705-6711, 2005.

Lee, A. K. Y., Herckes, P., Leaitch, W. R., Macdonald, A. M., and Abbatt, J. P. D.: Aqueous oh oxidation of ambient organic aerosol and cloud water organics: formation of highly oxidized products, Geophys. Res. Lett, 38, L11805, doi:10.1029/2011GL047439, 2011. 
Lee, A. K. Y., Hayden, K. L., Herckes, P., Leaitch, W. R., Liggio, J., Macdonald, A. M., and Abbatt, J. P. D.: Characterization of aerosol and cloud water at a mountain site during WACS 2010: secondary organic aerosol formation through oxidative cloud processing, Atmos. Chem. Phys., 12, 7103-7116, doi:10.5194/acp-12-7103-2012, 2012.

Lelieveld, J. and Crutzen, P. J.: The role of coulds in tropospheric photochemistry, J. Atmos. Chem., 12, 229-267, 1991.

Leriche, M., Voisin, D., Chaumerliac, N., Monod, A., and Aumont, B.: A model for tropospheric multiphase chemistry: application to one cloudy event during the cime experiment, Atmos. Environ., 34, 5015-5036, 2000.

Lim, H., Carlton, A. G., and Turpin, B. J.: Isoprene forms secondary organic aerosol through cloud processing: model simulations, Environ. Sci. Technol., 39, 4441-4446, 2005.

Lim, Y. B., Tan, Y., Perri, M. J., Seitzinger, S. P., and Turpin, B. J.: Aqueous chemistry and its role in secondary organic aerosol (SOA) formation, Atmos. Chem. Phys., 10, 1052110539, doi:10.5194/acp-10-10521-2010, 2010.

Madronich, S. and Flocke, S. J.: Theoretical estimation of biologically effective uv radiation at the Earth's surface, in: Solar Ultraviolet Radiation - Modelling, Measurement and Effects, edited by: Zerefos, C., Springer-Verlag, Berlin, 23-48, 1997.

Matsunaga, S. N., Guenther, A. B., Izawa, Y., Wiedinmyer, C., Greenberg, J. P., and Kawamura, K.: Importance of wet precipitation as a removal and transport process for atmospheric water soluble carbonyls, Atmos. Environ., 41, 790-796, doi:10.1016/j.atmosenv.2006.08.054, 2007.

Mazzoleni, L. R., Ehrmann, B. M., Shen, X. H., Marchall, A. G., and Collett, J. L.: Water-soluble atmospheric organic matter in fog: exact masses and chemical formula identification by ultrahigh-resolution fourier transform ion cyclotron resonance mass spectrometry, Environ. Sci. Technol., 44, 3690-3697, 2010.

McNeill, V. F., Woo, J. L., Kim, D. D., Schwier, A. N., Wannell, N. J., Sumner, A. J., and Barakat, J. M.: Aqueous-phase secondary organic aerosol and organosulfate formation in atmospheric aerosols: a modeling study, Environ. Sci. Technol., 46, 8075-8081, doi:10.1021/es3002986, 2012.

Monod, A. and Carlier, P.: Impact of clouds on the tropospheric ozone budget: direct effect of multiphase photochemistry of soluble organic compounds, Atmos. Environ., 33, 4431-4446, 1999.

Myriokefalitakis, S., Tsigaridis, K., Mihalopoulos, N., Sciare, J., Nenes, A., Kawamura, K., Segers, A., and Kanakidou, M.: In-cloud oxalate formation in the global troposphere: a 3-D modeling study, Atmos. Chem. Phys., 11, 5761-5782, doi:10.5194/acp-11-5761-2011, 2011.

Nathanson, G. M., Davidovits, P., Worsnop, D. R., and Kolb, C. E.: Dynamics and kinetics at the gas-liquid interface, J. Phys. Chem., 100, 13007-13020, 1996.

Nguyen, T. B., Roach, P. J., Laskin, J., Laskin, A., and Nizkorodov, S. A.: Effect of humidity on the composition of isoprene photooxidation secondary organic aerosol, Atmos. Chem. Phys., 11, 6931-6944, doi:10.5194/acp-11-6931-2011, 2011.

Pankow, J. F. and Barsanti, K. C.: The carbon number-polarity grid: a means to manage the 25 complexity of the mix of organic compounds when modeling atmospheric organic particulate matter, Atmos. Environ., 43, 2829-2835, 2009.

Paulot, F., Crounse, J. D., Kjaergaard, H. G., Kroll, J. H., Seinfeld, J. H., and Wennberg, P. O.: Isoprene photooxidation: new insights into the production of acids and organic nitrates, Atmos. Chem. Phys., 9, 1479-1501, doi:10.5194/acp-9-1479-2009, 2009a.

Paulot, F., Crounse, J. D., Kjaergaard, H. G., Kurten, A., St Clair, J. M., Seinfeld, J. H., and Wennberg, P. O.: Unexpected Epoxide Formation in the Gas-Phase Photooxidation of Isoprene, Science, 325, 730-733, 2009b.

Perrin, D. D., Dempsey, B., and Serjeant, E. P.: $\mathrm{pK}_{\mathrm{a}}$ prediction for organic acids and bases, Chapman And Hall, 1981.

Poulain, L., Katrib, Y., Isikli, E., Liu, Y., Wortham, H., Mirabel, P., Le Calve, S., and Monod, A.: In-cloud multiphase behaviour of acetone in the troposphere: Gas uptake, Henry's law equilibrium and aqueous phase photooxidation, Chemosphere, 81, 312-320, 2010.

Raventos-Duran, T., Camredon, M., Valorso, R., Mouchel-Vallon, C., and Aumont, B.: Structure-activity relationships to estimate the effective Henry's law constants of organics of atmospheric interest, Atmos. Chem. Phys., 10, 7643-7654, doi:10.5194/acp10-7643-2010, 2010.

Sander, S. P., Abbatt, J., Barker, J. R., Burkholder, J. B., Friedl, R. R., Golden, D. M., Huie, R. E., Kolb, C. E., Kurylo, M. J., Moortgat, G. K., Orkin, V. L., and Wine, P. H.: Chemical kinetics and photochemical data for use in atmospheric studies, evaluation no. 17, JPL Publication 10-6, Jet Propulsion Laboratory, Pasadena, California, http://jpldataeval.jpl.nasa.gov, 2011.

Schwartz, S. E.: Mass-transport considerations pertinent to aqueous phase reactions of gases in liquid-water clouds, NATO ASI Series, G6, 415-471, 1986.

Schwarzenbach, R. P., Gschwend, P. M., and Imboden, D. M., Equilibrium partitioning between gaseous, liquid, and solid phases, in: Environmental Organic Chemistry, John Wiley \& Sons, New York, 55-458, 2005.

Seinfeld, J. H. and Pandis, S. N.: Atmospheric chemistry and physics, from air pollution to climate change, John Wiley \& Sons, 2006.

Sorooshian, A., Ng, N. L., Chan, A. W. H., Feingold, G., Flagan, R. C., and Seinfeld, J. H.: Particulate organic acids and overall water-soluble aerosol composition measurements from the 2006 gulf of mexico atmospheric composition and climate study (GOMACCS), J. Geophys. Res.-Atmos., 112, D13201, doi:10.1029/2007JD008537, 2007.

Surratt, J. D., Chan, A. W. H., Eddingsaas, N. C., Chan, M. N., Loza, C. L., Kwan, A. J., Hersey, S. P., Flagan, R. C., Wennberg, P. O., and Seinfeld, J. H.: Reactive intermediates revealed in secondary organic aerosol formation from isoprene, P. Natl. Acad. Sci., 107, 6640-6645, 2010.

Tan, Y., Perri, M. J., Seitzinger, S. P., and Turpin, B. J.: Effects of precursor concentration and acidic sulfate in aqueous glyoxal-OH radical oxidation and implications for secondary organic aerosol., Environ. Sci. Technol., 43, 8105-8112, doi:10.1021/es901742f, 2009.

Tan, Y., Carlton, A. G., Seitzinger, S. P., and Turpin, B. J.: SOA from methylglyoxal in clouds and wet aerosols: Measurement and prediction of key products, Atmos. Environ., 44, 5218-5226, 2010.

Tilgner, A. and Herrmann, H.: Radical-driven carbonyl-to-acid conversion and acid degradation in tropospheric aqueous systems studied by capram, Atmos. Environ., 44, 5415-5422, 2010.

van Pinxteren, D., Plewka, A., Hofmann, D., Muller, K., Kramberger, H., Svrcina, B., Bachmann, K., Jaeschke, W., Mertes, 
S., Collett, J. L., and Herrmann, H.: Schmucke hill cap cloud and valley stations aerosol characterization during febuko (ii): organic compounds, Atmos. Environ., 39, 4305-4320, 2005.

Valorso, R., Aumont, B., Camredon, M., Raventos-Duran, T., Mouchel-Vallon, C., Ng, N. L., Seinfeld, J. H., Lee-Taylor, J., and Madronich, S.: Explicit modelling of SOA formation from $\alpha$-pinene photooxidation: sensitivity to vapour pressure estimation, Atmos. Chem. Phys., 11, 6895-6910, doi:10.5194/acp-116895-2011, 2011.

Volkamer, R., Ziemann, P. J., and Molina, M. J.: Secondary Organic Aerosol Formation from Acetylene $\left(\mathrm{C}_{2} \mathrm{H}_{2}\right)$ : seed effect on SOA yields due to organic photochemistry in the aerosol aqueous phase, Atmos. Chem. Phys., 9, 1907-1928, doi:10.5194/acp9-1907-2009, 2009.
Warneck, P.: Multi-phase chemistry of $\mathrm{C}_{2}$ and $\mathrm{C}_{3}$ organic compounds in the marine atmosphere, J. Atmos. Chem., 51, 119-159, 2005.

Zhou, Y., Zhang, H., Parikh, H. M., Chen, E. H., Rattanavaraha, W., Rosen, E. P., Wang, W., and Kamens, R. M.: Secondary organic aerosol formation from xylenes and mixtures of toluene and xylenes in an atmospheric urban hydrocarbon mixture: water and particle seed effects (ii), Atmos. Environ., 45, 3882-3890, 2011. 